\begin{tabular}{l|c|c}
\hline ISSN: 0001-5113 & ACTA ADRIAT., & ORIGINAL SCIENTIFIC PAPER \\
AADRAY & 58(1): $77-88,2017$ & \\
\hline
\end{tabular}

\title{
The vertical distribution and abundance of Chthamalus stellatus Poli and Chthamalus montagui Southward (Crustacea, Cirripedia) at two localities of the Istrian peninsula coast (North Adriatic)
}

\author{
Nataša DOLENC-ORBANIĆ*1 and Claudio BATTELLI ${ }^{2}$ \\ ${ }^{1}$ University of Primorska, Faculty of Education, Cankarjeva 5, 6000 Koper, Slovenia \\ ${ }^{2}$ Sergej Mašera 5, 6000 Koper, Slovenia
}

*Corresponding author, e-mail: natasa.dolenc@pef.upr.si

\begin{abstract}
Two species of chthamalid barnacles are well established from the upper to the lower limit of the midlittoral zone on the rocky shores of the North Adriatic Sea: Chthamalus stellatus, Poli and Chthamalus montagui, Southward. The present study deals with the vertical distribution and abundance for each species at two localities of the Istrian peninsula coast (North Adriatic Sea). For this purpose chthamalid populations were monitored in 2015 along the Slovenian marine coast (Bay of Koper, Gulf of Trieste) and along the Croatian marine coast, near Rovinj (west Istrian coast), both on limestone. The main aim of the study was to establish if there was a relationship between the vertical distribution and abundance of these two species at different spatial scales: small (between sites, about 1 kilometer) and large (between localities, 10 s of kilometers). The selected localities are slightly different in tidal range, in orientation and wave exposure. Three sites were randomly selected at each locality and two transects per tidal level (upper, middle and lower) were chosen on each site. The abundance of each chthamalids species in $1 \mathrm{dm}^{2}$ plots was determined at three different tidal levels along each transect. The results indicated that the vertical distribution of $\mathrm{C}$. montagui and C. stellatus was very similar between localities and even among sites, but their abundance varied. At both localities, C. montagui was more abundant in the upper and middle tidal levels, while C. stellatus was more abundant at the lower tidal level. It was also found that $\mathrm{C}$. montagui was more abundant in sheltered conditions (Bay of Koper), while C. stellatus on the coast more exposed to the wave action (near Rovinj), at all tidal levels.
\end{abstract}

Key words: Chthamalus montagui, C. stellatus, vertical distribution, abundance, spatial variations, midlittoral, North Adriatic

\section{INTRODUCTION}

Chthamalid barnacles are one of the most abundant and most characteristic sessile marine organisms of the midlittoral zone of the NE
Atlantic and Mediterranean rocky shores (STEPHENSON \& STEPHENSON, 1949; SOUTHWARD, 1950; LEWIS, 1964; BELLAN-SANTINI et al., 1994; PANNACCIULLI \& RELINI, 2000; SOUSA et al., 2000). For the Adriatic coasts, several authors 
have reported the presence of mainly two species of chthamalids in the midlittoral zone: Chthamalus montagui Southward and C. stellatus Poli (DANDO et al., 1979; ZAVODNIK, 1997; PANNACCIULLI \& RELINI, 2000; ZAVODNIK et al., 2000; 2005; 2006; IGIĆ, 2007).

Several studies related to the variability of the vertical (in relation to the tidal level) distribution and abundance of the $C$. stellatus and $C$. montagui in the midlittoral zone, to many factors, such as: tidal level, shore exposure to wave action, sea temperature, coastal topography, substrate type, recruitment, post-larval mortality, and interspecific competition (CONNELL, 1961; SOUTHWARD, 1976; BURROWS, 1988; SOUTHWARD, 1991; BENEDETTI-CECCHI et al., 2000; DELANY et al., 2003; HISCOCK et al., 2004; O'RIORDAN et al., 2004; HERBERT et al., 2007). Among these factors, shore exposure to wave action and tidal level are considered to be the most important (SOUTHWARD, 1976; BURROWS, 1988; CRISP et al., 1981; PANNACCIULLI \& RELINI, 2000; SOUSA et al., 2000; JENKINS, 2005; POWER et al., 2006; O'RIORDAN et al., 2010). As shown by these authors $C$. stellatus was more abundant at exposed sites and tended to occupy lower tidal levels, while C. montagui was more abundant in sheltered places and at higher tidal levels. O'RIORDAN et al. (2010) reported that the distribution of C. montagui and C. stellatus differ also at the small, local and large, regional scale. They noted that at local and regional scales abiotic factors, such as desiccation, temperature, wind, and wave exposure might affect the distribution of chthamalids. Several studies indicated that tolerance of the highly fluctuating temperature and desiccation stress are considered to be the main factors that control the distribution of chthamalids species. For example, BURROWS (1988), POWER et al. (2001, 2006, 2011) documented that $C$. montagui is more resistant to desiccation than $C$. stellatus.

Little is known about the vertical distribution on the local and regional scales of $C$. montagui and C. stellatus on the North Adriatic rocky shore. The only works were published by PANNACCIULLI \& RELINI (2000) and PITACCO et al. (2013), but they were limited to the Gulf of Trieste. The authors observed that these species occupy all tidal levels of the midlittoral zone but their abundance varies from level to level: $C$. montagui has been found to be more common in the upper and in the middle tidal level, while C. stellatus is in the lower level. The results of the study conducted along the Slovenian coast by BATTELLI \& DOLENC ORBANIĆ (2008; 2009) revealed a very similar situation, where the two species co-occur.

Our work deals with the vertical distribution and the abundance of two species of chthamalids, C. montagui and C. stellatus at two localities along the Istrian peninsula coast: one located along the coast of the Bay of Koper (Gulf of Trieste) and one in a broader geographical area, along the west Istrian coast, near Rovinj.

The main aims of the study were: (a) to determine the pattern of vertical distribution and the abundance of the two co-occurring selected species in the midlittoral zone at two investigated localities, and (b) to establish if there was a relationship between the vertical distribution and the abundance of these two species on a small, local spatial scale (among sites, within each locality, of about 1 kilometer), and on a large, regional scale (between localities, 10s of kilometers).

\section{MATERIAL AND METHODS}

\section{Study area}

The main characteristics of the North Adriatic Sea are its relatively high tidal range (up to $1 \mathrm{~m}$ ), with high temperature and salinity variations, wind-driven water circulation, stratification of its water column, nutrient discharges by rivers, and high productivity (STRAVISI, 1983; STACHOWITSCH, 1991; VUČAK, 1996). The study was carried out in two localities situated along the Istrian peninsula coast (North Adriatic Sea) (Fig. 1).

The first locality (Lo1) comprised three sites (Si1, Si2, and Si3) located along the Slovenian coast (Bay of Koper), in the southeastern part of the Gulf of Trieste. The depth inside the Gulf is around $15 \mathrm{~m}$, with a maximum of $25 \mathrm{~m}$ in the central part. The embayed situation of the Gulf, 


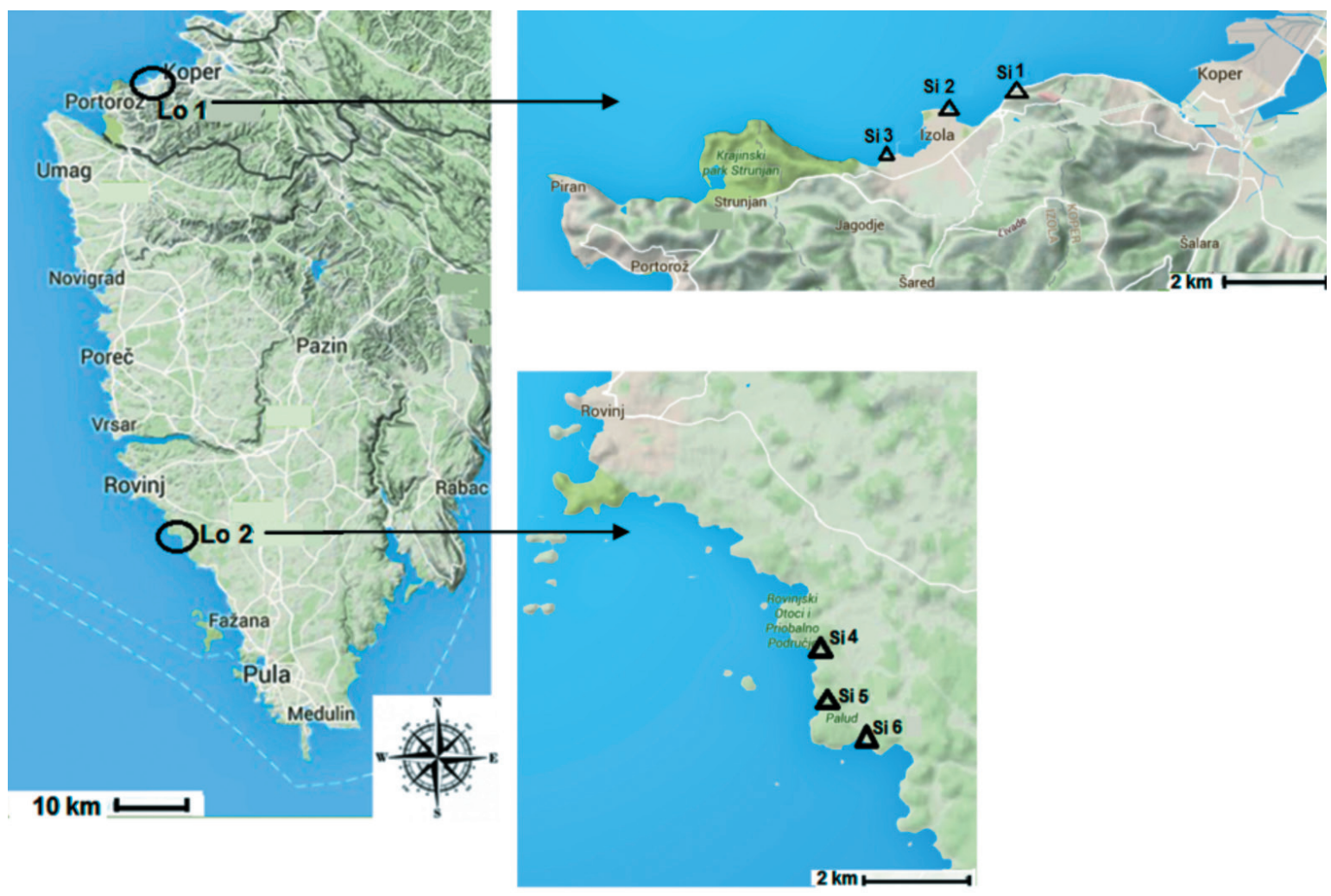

Fig. 1. Map of the investigated area indicating the sampling localities (left) and corresponding sites (right)

the dominant winds blowing offshore (from the Northeast) and very shallow waters create a quite sheltered condition (PANNACIULLI \& RELINI, 2000; MALAČIČ \& JEROMEL, 2005).

Site Sil was situated along the coast between Koper and Izola $\left(45^{\circ} 32^{\prime} 49^{\prime \prime} \mathrm{N}, 13^{\circ} 41^{\prime} 11^{\prime \prime} \mathrm{E}\right)$. The shore formed from limestone breakwater rocks was exposed to wave action and winds blowing from the southwest to the northeast (MALAČIČ \& JEROMEL, 2005). Site Si2 was situated on the northern part of Izola $\left(45^{\circ} 32^{\prime} 32^{\prime \prime}\right.$ $\left.\mathrm{N}, 13^{\circ} 39^{\prime} 42^{\prime \prime} \mathrm{E}\right)$, while site $\mathrm{Si} 3$ was located in St. Simon Bay ( $45^{\circ} 32^{\prime} 04^{\prime \prime}$ N, $13^{\circ} 38^{\prime} 47^{\prime \prime}$ E). The substratum of the sites $\mathrm{Si} 2$ and $\mathrm{Si} 3$ consisted of limestone (PAVLOVEC, 1985), and had a generally more irregular and heterogeneous structure, with many outcrops and crevices of various sizes. The wind exposure was northwesterly and northeasterly (MALAČIČ \& JEROMEL, 2005).

The second one (Lo2), about $65 \mathrm{~km}$ as the crow flies from Lo1, lying along the Croatian, west Istrian coast, near Rovinj, comprised the site $\mathrm{Si} 4\left(45^{\circ} 02^{\prime} 02^{\prime \prime} \mathrm{N}\right.$; $\left.13^{\circ} 41^{\prime} 27^{\prime \prime} \mathrm{E}\right)$, site
$\operatorname{Si} 5$ ( $\left.45^{\circ} 01^{\prime} 46^{\prime \prime} \mathrm{N} ; 13^{\circ} 41^{\prime} 34^{\prime \prime} \mathrm{E}\right)$, and site Si6 ( $\left.45^{\circ} 01^{\prime} 27^{\prime \prime} \mathrm{N} ; 13^{\circ} 42^{\prime} 07^{\prime \prime} \mathrm{E}\right)$. All of them were situated south of Rovinj and were exposed to westerly winds (SMIRČIĆ et. al, 1996; ZAVODNIK et al., 2002). Locality Lo 2 was characterized by a limestone rocky substratum; the structure of the substratum was similar to that described for $\mathrm{Si} 2$ and Si3. The depth of the sea near Rovinj (Lo2) was around 20-40 m, which was deeper than in the Gulf of Trieste (Lo1).

In the North Adriatic the vertical extent of the midlittoral zone, ranging between the mean higher high water (MHHW) and the mean lower low water (MLLW) tide levels, was at Lo1 approximately $90 \mathrm{~cm}$, and at Lo2 $67 \mathrm{~cm}$ (VUČAK, 1996). Based on our field observations three levels were clearly recognized at all sites of the selected localities: upper, middle, and lower, as proposed by BATTELLI (2016) for the Gulf of Trieste. The upper level of this zone ranges from a mean higher high water (MHHW) to a mean high water (MHW) tide level. Among the fauna, the most characteristic components 
were populations of chthamalids. The middle level extends from MHW to a mean low water (MLW) tide level. The chthamalids of this level were mixed with other faunal species such as gastropods (Monodonta sp., Gibbula sp, Patella sp.) and anthozoans (Actinia sp.). The lower level ranges from MLW to MLLW tidal levels. It was mainly occupied by aggregates of the bivalve Mytilus galloprovincialis.

It is important to note that while the two selected localities are similar regarding the type of substratum, they slightly differ in the mean tidal amplitude (VUČAK, 1996), in orientation (Lo1 to north, Lo2 to west), in exposure to wave action (Lo2 is more exposed than Lo1) (SMIRČIĆ et. al, 1996), and in the depth of the coastal sea (deeper at Lo2). Lo2 is exposed to the open sea (ZAVODNIK, 1967; ZAVODNIK et al., 2002), while Lo1 in a semi-enclosed shallow area (MALAČIČ \& JEROMEL, 2005).

\section{Methods}

Sampling was carried out in September 2015. Three sites of the midlittoral zone (about $1 \mathrm{~km}$ apart, $60 \mathrm{~m}$ in length) within each locality were randomly chosen. Each site was divided into 12 transects (5 $\mathrm{m}$ in length) and each transect in three tidal levels (upper, middle and lower). At each tidal level, two transects were randomly selected for each species (6 sampled areas for each species). Within each area, three plots $(10 \mathrm{~cm}$ x $10 \mathrm{~cm})$ were analyzed. Only areas where chthamalids were more abundant and formed a homogeneous community along the whole transect were selected. The abundance was determined by counting the individuals directly from each plot during the fieldwork with a magnifier hand lens. Counts were made for each species in separate plots to maintain the independence of the samples for statistical purposes. Only adult chthamalids were counted. We considered adults after POWER et al. (2001), as all individuals that were more than $2 \mathrm{~mm}$ in opercular diameter. For the identification of the selected chthamalids species we only used the external morphological features, according to the works of SOUTHWARD (1976), RELINI (1980), and BATTELLI \& DOLENC-ORBANIĆ (2009), as follows: (a) the shape of the opercular opening, (b) the shape of the adductor muscle scar, and (c) the position and curvature of the articulation between the terga and scuta.

\section{Data analysis}

In order to determine the vertical distribution pattern and the abundance of Chthamalus montagui and $C$. stellatus on different spatial scales (small - among sites, and large - between localities), the data were analyzed using the GraphPad Prism 5.02 program.

The non-parametric Kruskal-Wallis H-test (KRUSKAL \& WALLIS, 1952) was used in order to indicate statistically significant differences in mean abundance of chthamalids (at each tidal level) among sites within a single locality, separately for both species. In order to establish whether there was a statistically significant difference in the mean abundance of the two chthamalids species (at each tidal level) between localities, the Mann-Whitney U-test (MANN \& WHITNEY, 1947), was performed. The data were expressed as the mean \pm SE (standard error of mean).

\section{RESULTS}

\section{Vertical distribution and abundance}

The main aim of our study was to establish whether there was a relationship between vertical distribution and abundance of $C$. montagui and $C$. stellatus at different spatial scales: small (among sites) and large (between localities).

The results of our study indicated that the distribution of these species was confined between the upper and the lower limit of the midlittoral zone on the rocky shore of both of the selected localities. During the investigation, we found that at both localities these two chthamalid species co-occurred at all levels (upper, middle, lower) of the midlittoral zones. The results revealed that $C$. montagui was more abundant (mean number $/ \mathrm{dm}^{2}=39.00 \pm \mathrm{SE}$ ) than C. stellatus (mean number $/ \mathrm{dm}^{2}=5.14 \pm \mathrm{SE}$ ) at 


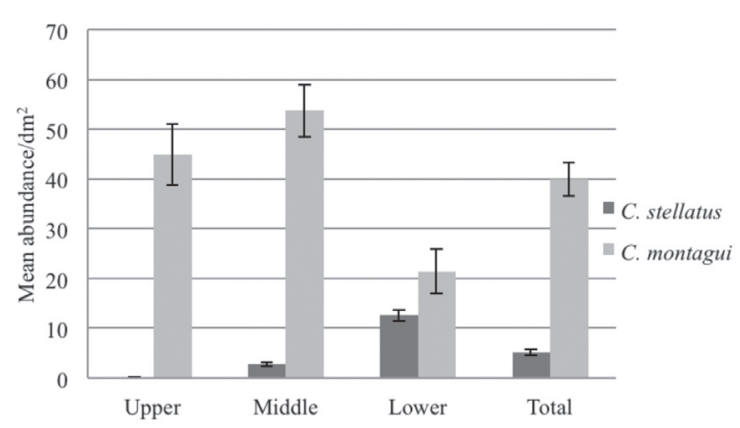

Fig. 2. The mean abundance $( \pm S E)$ of Chthamalus stellatus and $\mathrm{C}$. montagui according to the tidal level and the total abundance of both species at the research area, Izola (three sites) and Rovinj (three sites)

all levels and at all the considered sites at both localities (Fig. 2), although the pattern of abundance of the single species among levels was different. The highest mean abundance (12.56 \pm $\mathrm{SE})$ of $C$. stellatus was found in the lower level and the lowest $(0.08 \pm \mathrm{SE})$ in the upper, while for $C$. montagui the highest mean abundance was in the middle (53.72 $\pm \mathrm{SE})$ and the lowest in the lower (21.44 $\pm \mathrm{SE})$. From Fig. 2, a great difference between the abundance of the two selected species in the upper and in the middle level of the midlittoral zone, was evident. The Mann-Whitney U test showed that the differences in the total mean abundance between the two species at the research area at all levels were statistically significant $(U=1215, \mathrm{p}<0.0001)$. At the upper and middle level the differences were significant $(U=0.0000, \mathrm{p}<0.001 ; U=16.00$, $p<0.001$ respectively), while the difference in the lower level was statistically not significant.

\section{Comparison in the mean abundance of two chthamalids species among the sites}

A considerable variability in the mean abundance of $C$. montagui on small spatial scales (among sites) at locality Lo1 (Izola) was found. From Fig. 3a it is evident that this species was more abundant at the upper and middle tidal level than at the lower level. The Kruskal-Wallis test showed statistically significant differences in abundance at the upper level $(\mathrm{H}=6.50, \mathrm{df}=$ $2, \mathrm{p}=0.0389)$, between site $\mathrm{Si} 1$ and site $\mathrm{Si} 2$; at the middle level $(H=14.34$, $d f=2, p=0.0008)$, between site $\mathrm{Si} 1$ and site $\mathrm{Si} 3$, and at the lower level $(\mathrm{H}=10.13$, $\mathrm{df}=2, \mathrm{p}=0.0063)$ between site Sil and site Si3.

Statistically significant differences in abundance among sites were also found at locality Lo2 (Rovinj): at the upper level $(\mathrm{H}$ $=11.09, \mathrm{df}=2, \mathrm{p}=0.0039)$ between site $\mathrm{Si} 4$ and site $\mathrm{Si} 5$; at the middle level $(\mathrm{H}=11.82$, df $=2, \mathrm{p}=0.0027)$ between site Si5 and site Si6 and lower level $(\mathrm{H}=8.12, \mathrm{df}=2, \mathrm{p}=0.0172)$ between site $\mathrm{Si} 4$ and site Si5. The Fig. 3b shows that $C$. montagui reached the highest abundance at the middle tidal level and the lowest at the lower level.

For C. stellatus at the locality Lo1, the Kruskal-Wallis test showed a statistically significant difference in the mean abundance
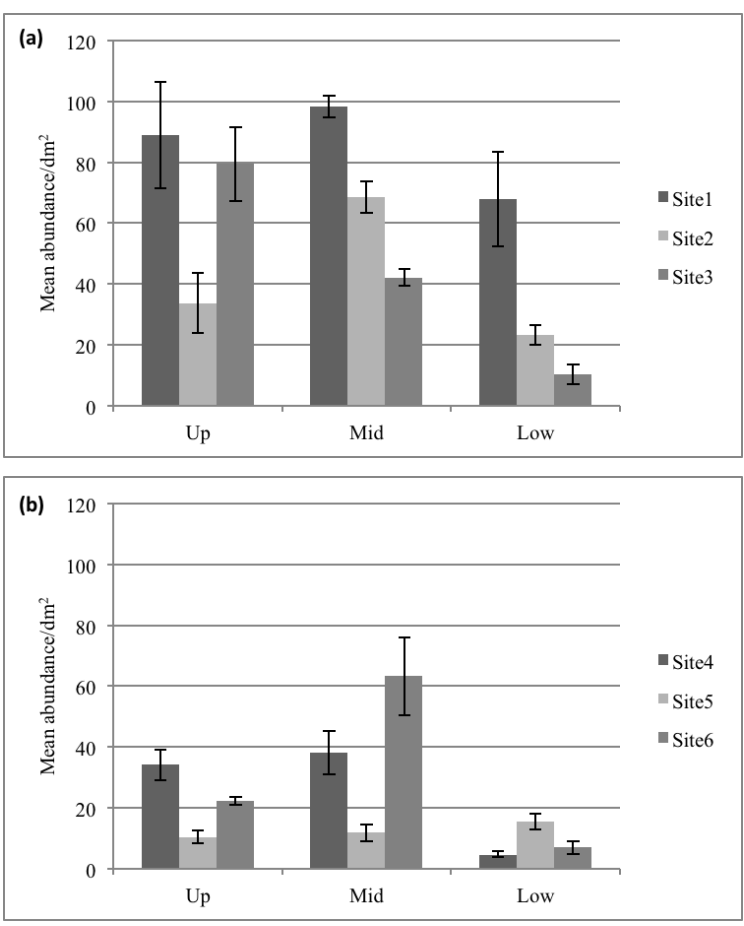

Fig.3. Comparison of the mean abundance ( \pm SE) of Chthamalus montagui, among the sites, at the upper (up), middle (mid), and the lower level (low) of the midlittoral zone at (a) locality 1 (Izola) and (b) locality 2 (Rovinj)

only for the middle level $(\mathrm{H}=7.37$, $\mathrm{df}=2, \mathrm{p}=$ $0.0252)$ between site Si1 and site Si2 $(\mathrm{p}<0.05)$, while at locality Lo2 the differences among the sites were not statistically significant. The abundance of this species was higher at the 
lower tidal level compared with the other tidal levels at both localities (Fig. 4a and 4b).
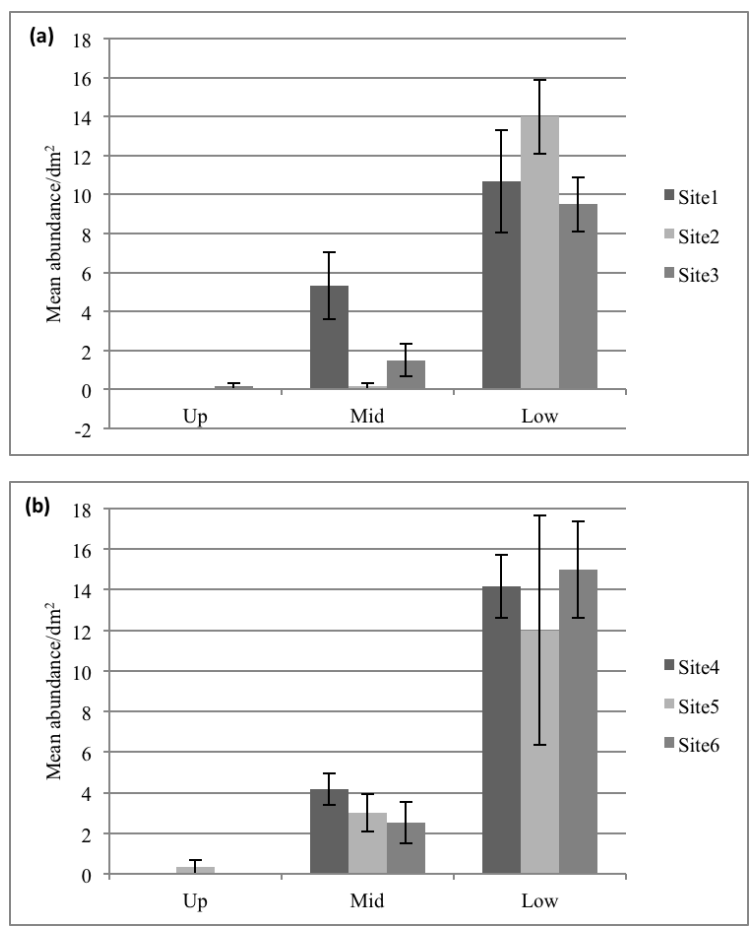

Fig.4. Comparison of the mean abundance ( $\pm S E$ ) of Chthamalus stellatus, among the sites, at the upper (up), middle (mid), and lower level (low) of the midlittoral zone at (a) locality 1 (Izola) and (b) locality 2 (Rovinj)

\section{Comparison of the mean abundance of two chthamalids species between localities}

A marked spatial variability in the mean abundance of $C$. montagui at the large scale (between localities) at each tidal level was found, as evident from Fig. 5a and Fig. 5b.

In the upper level the mean abundance $(67.30 \pm \mathrm{SE})$ of C. montagui at locality Lo1 was significantly $(\mathrm{U}=59.00, \mathrm{p}=0.0012)$ higher than at locality Lo2 $(22.28 \pm \mathrm{SE})$. A very similar trend was found for the middle $(\mathrm{U}=63.00, \mathrm{p}=$ $0.0018)$ and the lower tidal level $(\mathrm{U}=61.00, \mathrm{p}=$ $0.0015)$ (Fig. 5a).

The vertical distribution pattern of the abundance of $C$. stellatus among the levels was very similar at both localities, although the abundance at Lo2 was slightly higher than at Lo1 (Fig. 5a and 5b). The minimum values of the abundance of $C$. stellatus were found at the upper level at both localities (Lo1 $=0.06 \pm$ $\mathrm{SE} ; \mathrm{Lo} 2=0.11 \pm \mathrm{SE}$ ), and the maximum at the lower (Lo1: $11.39 \pm \mathrm{SE}$; Lo2: $13.72 \pm \mathrm{SE})$. The Mann-Whitney $U$ test revealed no statistically significant difference in mean abundance between the localities within each level.
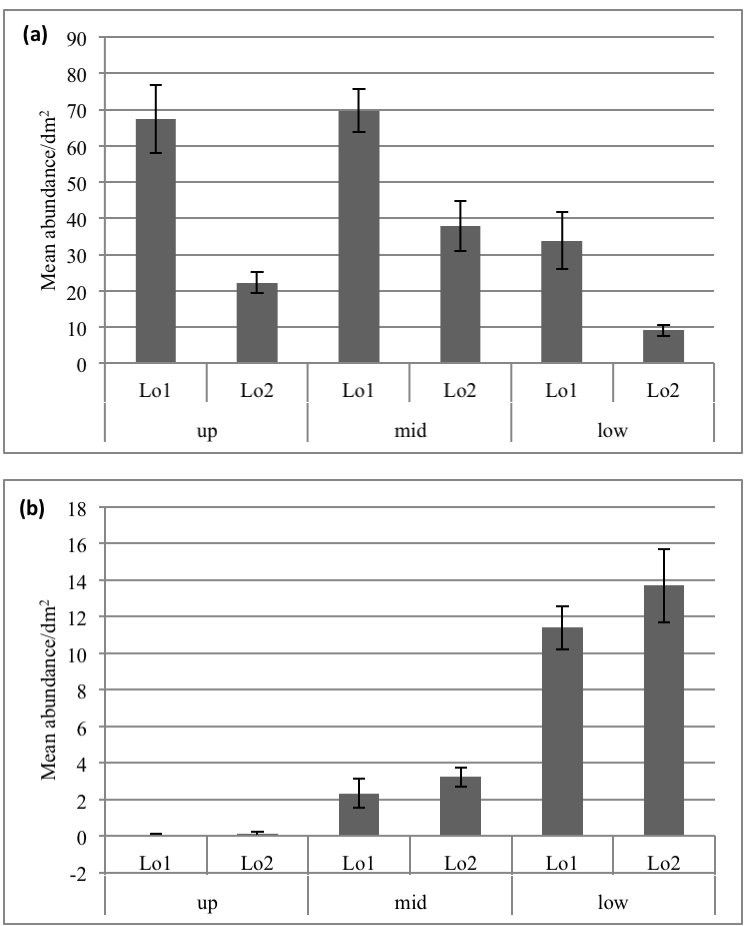

Fig. 5. Comparison of the mean abundance ( $\pm S E$ ) of (a) Chthamalus montagui and (b) C. stellatus between localities (Lo1-Izola and Lo2-Rovinj), at the upper (up), middle (mid), and lower level (low) of the midlittoral zone

\section{DISCUSSION}

The results of our investigations showed that the distribution of both chthamalids species, Chthamalus montagui and C. stellatus, were confined to the midlittoral zone, ranging between the upper and the lower limit of this zone on the rocky shore of the research areas. These observations were similar to those for the Gulf of Trieste (North Adriatic Sea) but in contrast to the Gulf of Genova (Ligurian Sea), where, as reported by PANNACCIULLI \& RELINI (2000), the distribution of these two species stretched further up as wave action prevails over the tides. BURROWS et al. (1992) noted that $C$. montagui has a greater vertical 
distribution, extending above and below that of C. stellatus. One possible explanation is that $C$. montagui has a greater resistance to desiccation stress compared with C. stellatus. FOSTER (1971) observed that desiccation is a lethal factor which may determine the upper limit of barnacles and CRISP et al. (1981) found that C. stellatus reached its largest numbers in places shaded from the direct sun.

Several factors probably interact to create the patterns of vertical distribution of the investigated Chthamalus species. Many studies conducted for the Mediterranean and NE Atlantic rocky shores (e.g. SOUTHWARD, 1976; CRISP et al., 1981; BURROWS, 1988; SOUSA et al., 2000; POWER, 2000; O'RIORDAN et al., 2004) have revealed that the tidal amplitude and the wave exposure are the major factors that significantly determine the vertical distribution of chthamalids in the midlittoral zone, and even that different species can be separated by these factors.

We found that in the midlittoral zone of the research area $C$. montagui was dominant over C. stellatus, which was in accordance with the results of the study of SOUSA et al. (2000) along the southern coast of Portugal, and PANNACCIULLI \& RELINI (2000) for the Gulf of Trieste. The opposite situation was described by PANNACCIULLI \& RELINI (2000) for Genova and by BEŞIR \& ÇINAR (2012) for Antalya Bay (Eastern Mediterranean Sea), where C. stellatus was dominant.

The results of this study indicated that the vertical distribution and the abundance of each of the investigated Chthamalus species were different at various (upper, middle, and lower) tidal levels: C. montagui was more abundant in the middle and upper tidal level than in the lower, while C. stellatus was more abundant in the lower than at the other levels. This agrees with several studies of different European areas, such as the Gulf of Trieste (PANNACCIULLI \& RELINI, 2000), the NE Atlantic coast (SOUTHWARD, 1976; BURROWS, 1988; CRISP et al., 1981), and Southwest coast of Portugal (SOUSA et al., 2000). The opposite pattern was observed by BENEDETTI-CECCHI et al. (1999) and MENCONI et al. (1999) in the northwest Mediterranean, where C. stellatus was more abundant in high-shore habitats. As reported in many works (e.g. SOUTHWARD, 1976; BURROWS, 1988; POWER et al., 2001; 2006; 2011) the differences in abundance of C. montagui and C. stellatus at each tidal level has been associated with desiccation. SOUTHWARD (1955) highlighted that the higher the species occurred up on the shore, the more resistant to desiccation influences they tend to be. BURROWS (1988), for example, observed that $C$. montagui is more tolerant towards high temperatures and desiccation than C. stellatus due to morphological differences in the shape of the opercular plates: the opercular plates of C. montagui are more closely-fitting than those of $C$. stellatus.

A different pattern of the abundance of each of the Chthamalus species was observed at a large, regional spatial scale (between localities). It is important to note that the two selected localities were similar in the type of substratum, but slightly different in tidal amplitude, in orientation and wave exposure. Lo1 was a semi-enclosed embayed area, oriented to the north, characterized by very shallow waters and moderate wave action, which create a sheltered condition. On the contrary, Lo2 was oriented to the west, exposed to the open sea, with a stronger wave action and deeper coastal sea. The analyses indicated that the abundance of C. montagui was higher at Lo1 than at Lo2, at each tidal level, while $C$. stellatus was more abundant at Lo2 at all tidal levels. This is in accordance with several authors (e.g. SOUSA et al., 2000; POWER et al. 2001; JENKINS, 2005) who have found that the abundance of both Chthamalus species, at each tidal level, differ along a wave exposure gradient.

Since the difference in tidal amplitude between the two selected localities was small, we are inclined to consider that the exposure of the shores to the wave action is one of the most significant factors in determining the differences in the pattern of vertical distribution and abundance observed for each of the investigated Chthamalus species. The results of our study are similar to those found in other studies. Several authors (e.g. SOUTHWARD, 1976; CRISP et al., 1981; PANNACCIULLI \&RELINI, 2000; POWER et al., 2001, 
2006, 2011) observed that $C$. stellatus was more abundant on the coasts more exposed to wave action or wet and shady places, as noted by PANNACCIULLI \& RELINI (2000) for Genova and by BEŞIR \& ÇINAR (2012) for Antalya Bay. In contrast, C. montagui reached peak abundance where the wave action was reduced and where the tidal amplitude was high, about $1 \mathrm{~m}$, as reported by PANNACCIULLI \& RELINI (2000) for the Gulf of Trieste, which is in agreement with the present study. One possible explanation is that the physical stress due to the wave action could be more variable at the upper and middle levels than at the low tidal level, due to the longer immersion period of the lower level. Another explanation is the difference in larval settlement and post-settlement processes. DELANY et al. (2003) considered post-settlement mortality, rather than larval supply, to be the more significant factor in determining the characteristic patterns of these chthamalid species. As noted by JENKINS (2005) the adult distribution across the wave exposure gradient may be determined at settlement. The larval settlement choice rather than a differential larval supply determined the setting-up of species vertical zones. C. stellatus cyprids have been proposed to be better adapted to settle or the adults survive in wave-exposed areas (CRISP et al., 1981; POWER et al. 2001).

A significant difference in the abundance on a small, local spatial scale (among sites within each locality), were detected for both species. The patterns of vertical distribution and the abundance of $C$. montagui revealed a statistically consistent difference among the sites at each tidal level at both localities. We observed that, in general, this species was more abundant in the upper and middle tidal levels than in the lower levels at both localities. In contrast to C. montagui, at each site of both localities, the abundance of $C$. stellatus was higher in the lower tidal level compared with the other tidal levels. For this species, the only statistically significant difference in the mean abundance among the sites of Lo1 was found in the middle level, while at Lo2 these differences were not statistically significant. This variability can be due to small-scale variations in the settlement and post-settlement processes on shores with different degrees of wave action as noted by CAFFEY (1982). Several authors (e.g. BURROWS, 1988; POWER et al., 2001; 2006) in their work suggested that abiotic factors such as temperature and desiccation are the major determinants of the distribution patterns of chthamalids, that $C$. montagui survives better in desiccating microhabitats than $C$. stellatus, and that the mortality of C. montagui is lower in desiccating tidal regimes compared with $C$. stellatus.

\section{CONCLUSIONS}

In conclusion, the results of our investigation showed a very similar pattern of vertical distribution, but a considerable variability in the abundance of each of the investigated Chthamalus species on a small, local spatial scale (among sites) and on a large, regional spatial scale (between localities). This study demonstrated that:

1. The pattern of vertical distribution of Chthamalus montagui and C. stellatus ranged between the upper and the lower limits of the midlittoral zone on the rocky shore of the research areas.

2. At both selected localities C. montagui was more abundant in the upper and middle tidal levels, while $C$. stellatus was more abundant at the lower tidal level.

3. C. stellatus was more abundant than $C$. montagui on the shore more exposed to wave action (Lo2), while C. montagui was more abundant on more sheltered shores (Lo1).

Several factors probably affect the distribution pattern and the abundance of the investigated Chthamalus species. In our opinion, more extensive studies, incorporating a larger number of localities and factors, are necessary to gain a better understanding and to clarify the vertical distribution and abundance of C. montagui and C. stellatus in the North Adriatic.

\section{ACKNOWLEDGEMENTS}

Our cordial thanks to Fabio BULLERI for his help with the sampling design of this study. Special thanks to anonymous reviewers whose valuable suggestions made a substantial contribution to the manuscript. 


\section{REFERENCES}

BATTELLI, C. \& N. DOLENC-ORBANIĆ. 2008. First record of Chthamalus montagui Southward, 1976 (Crustacea, Cirripedia) on the Slovenian coast (Gulf of Trieste, Northern Sea). Annales Ser. Hist. Nat., 18 (1): 73-78.

BATTELLI, C. \& N. DOLENC-ORBANIĆ. 2009. Contribution to the knowledge of the chthamalids (Crustacea, Cirripedia) on the Slovene rocky shore (Gulf of Trieste, North Adriatic Sea) - Prispevek k poznavanju vitičnjakov (crustacea, cirripedia) na kamnitem slovenskem obrežju (Tržaški zaliv, severno Jadransko morje). Varstvo Narave, 22: 81-90.

BATTELLI, C. 2016. A new proposal for zonation of the midlittoral in the Bay of Koper (Gulf of Trieste, northern Adriatic) based on macroalgal communities. Acta Adriat., 57(1): 63-80.

BELLAN-SANTINI, D., J.C. LACAZE \& C. POIZAT. 1994. Les Biocénoses marines et littorales de Méditerranée. Synthèse, menaces et perspectives. Museum National d'Histoire Naturelle, Paris. 246 p.

BENEDETTI-CECCHI, L., M. MENCONI \& F. CINEILI. 1999. Pre-emption of the substratum and the maintenance of spatial pattern on a rocky shore in the northwest Mediterranean. Mar. Ecol. Prog. Ser., 181: 13-23.

BENEDETTI-CECCHI, L., S. ACUNTO, F. BULLERI \&

F. CINELLI. 2000. Population ecology of the barnacle Chthamalus stellatus in the northwest Mediterranean. Mar. Ecol. Prog. Ser., 198: 157-170.

BEŞIR, C. \& M.E. ÇINAR. 2012. Thoracic cirripeds (Thoracica: Cirripedia) from Antalya Bay (Eastern Mediterranean). J. Black Sea/Mediterranean Environment, 18(2): 251-270.

BURROWS, M.T. 1988. The comparative biology of Chthamalus stellatus (Poli) and Chthamalus montagui Southward. Ph. D. Thesis, University of Manchester, $318 \mathrm{pp}$.

BURROWS, M.T., S.J. HAWKINS \& A.J. SOUTHWARD. 1992. A comparison of reproduction in cooccurring chthamalid barnacles Chthamalus stellatus (Poli) and Chthamalus montagui
Southward. J. Exp. Mar. Biol. Ecol., 160: 229-249.

CAFFEY, H. 1982. No effect of naturally occurring rock types on settlement or survival in the intertidal barnacle, Tesseropora rosea (Krauss). J. Exp. Mar. Biol. Ecol., 63: 119132.

CONNELL, J. H. 1961. The influence of interspecific competition and other factors on the distribution of the barnacle Chthamalus stellatus. Ecology, 42(4): 710-723.

CRISP, D.J., A.J. SOUTHWARD \& E.C. SOUTHWARD. 1981. On the distribution of the intertidal barnacles Chthamalus stellatus, Chthamalus montagui and Euraphia depressa. J. Mar. Biol. Ass. U.K., 61: 359-380.

DANDO, P.R., A.J. SOUTHWARD \& D.J. CRISP. 1979. Enzyme variation in Chthamalus stellatus and Chthamalus montagui (Crustacea Cirripedia): Evidence for the presence of $C$. montagui in the Adriatic. J. Mar. Biol. Ass. U.K., 59: 307-320.

DELANY, J., A.A. MYERS, D. McGRATH, R.M. O'RIORDAN \& A.M. POWER. 2003. Role of postsettlement mortality and 'supply-side' ecology in setting patterns of intertidal distribution in the chthamalid barnacles Chthamalus montagui and C. stellatus. Mar. Ecol. Prog. Ser., 249: 207- 214.

FOSTER, B.A. 1971. Desiccation as a factor in the intertidal zonation of barnacles. Mar. Biol., 8: $12-29$.

HERBERT, R.J.H., A.J. SOUTHWARD, M. SHEADER \& S.J. HAWKINS. 2007. Influence of recruitment and temperature on distribution of intertidal barnacles in the English Channel. J. Mar. Biol. Ass. U.K., 87: 487-499.

HISCOCK, K., A.J. SOUTHWARD, I. TITTLEY \& S. HAWKINS. 2004. Effects of changing temperature on benthic marine life in Britain and Ireland. Aquat. Conserv. Mar. Freshwater Ecosyst., 14: 333-362.

IGIĆ, LJ. 2007. Cirripedia of Adriatic. Stud. Mar. Kotor, 24(2): 1-167.

JENKINS, S.R. 2005. Larval habitat selection, not 
larval supply, determines settlement patterns and adult distribution in two chthamalid barnacles. J. Anim. Ecol., 74(5): 893-904.

KRUSKAL, W.H. \& W.A. WALLIS. 1952. Use of ranks in one-criterion variance analysis. J. Am. Stat. Assoc., 47: 583-621.

LEWIS, J. R. 1964. The Ecology of Rocky Shores. The English Universities Press Ltd., London, $323 \mathrm{pp}$.

MALAČIČ, V. \& M. JEROMEL. 2005. Vetrovi ob Slovenski obali-tablice. Nacionalni inštitut za biologijo, Morska biološka postaja. Piran, 2 pp.

MANN, H.B. \& D.R. WHITNEY. 1947. On a Test of Whether one of Two Random Variables is Stochastically Larger than the Other. Ann. Math. Statist., 18 (1): 50-60. doi:10.1214/aoms/1177730491. MR 22058. Zbl 0041.26103.

MENCONI, M., L. BENEDETTI-CECCHI \& F. CINELLI. 1999. Spatial and temporal variability in the distribution of algae and invertebrates on rocky shores in the North West Mediterranean. J. Exp. Mar. Biol. Ecol., 233: 1-23.

O'RIORDAN, R. M., F. ARENAS, J. ARRONTES, J.J. CASTRO, T. CRUZ, J. DELANY, B. MARTÍNEZ, C. FERNANDEZ, S.J. HAWKINS, D. McGRATH \& A.M. POWER. 2004. Spatial variation in the recruitment of the intertidal barnacles Chthamalus montagui Southward and Chthamalus stellatus (Poli) (Crustacea: Cirripedia) over an European scale. J. Exp. Mar. Biol. Ecol., 304: 243-264.

O'RIORDAN, R.M., A.M. POWER\&A.A. MYERS. 2010. Factors, at different scales, affecting the distribution of species of the genus Chthamalus Ranzani (Cirripedia, Balanomorpha, Chthamaloidea). J. Exp. Mar. Biol. Ecol., 392 (1-2): 46-64.

PANNACCIULLI, F.G. \& G. RELINI. 2000. The vertical distribution of Chthamalus montagui and Chthamalus stellatus (Crustacea, Cirripedia) in two areas of the NW Mediterranean Sea. Hydrobiologia, 426: 105-112.

PAVLOVEC, R. 1985. Numulitine iz apnencev pri Izoli (SW Slovenija). Razprave 4. razred SAZU, 26: 219-230.

PITACCO, V., B. MAVRIČ, M. ORLANDO-BONACA \& L. LIPEJ. 2013. Rocky macrozoobenthos medi- olittoral community in the Gulf of Trieste (North Adriatic) along a gradient of hydromorphological modifications. Acta Adriat., 54(1): 67-86.

POWER, A.M., 2000. The ecology of chthamalid barnacles. An evaluation of settlement and recruitment in regulating the intertidal distribution of Chthamalus stellatus and $C$. montagui in south-west Ireland. PhD thesis. National University of Ireland, Cork.

POWER, A.M., A.A. MYERS, R.M. O' RIORDAN, D. McGRATH \& J. DELANY. 2001. An investigation into rock surface wetness as a parameter contributing to the distribution of the intertidal barnacles Chthamalus stellatus and C. montagui. Estuar. Coast. Shelf Sci., 52: 349-356.

POWER, A.M., J. DELANY, D. McGRATH, A.A. MYERS \& R.M. O' RIORDAN. 2006. Patterns of adult abundance in Chthamalus stellatus (Poli) and C. montagui Southward (Crustacea: Cirripedia) emerge during late recruitment. J. Exp. Mar. Biol. Ecol., 332: 151-165.

POWER, A.M., K. McKRANN, D. McGRATH, R.M. O' RIORDAN, C. SIMKANIN \& A.A. MYERS. 2011. Physiological tolerance predicts species composition at different scales in a barnacle guild. Mar. Biol., 158: 2149-2160.

RELINI, G. 1980. Cirripedi Toracici. Guide per il riconoscimento delle specie animali delle acque lagunari e costiere italiane, 2. Consiglio Nazionale delle Ricerche: Genova, $116 \mathrm{pp}$.

SMIRČIĆ, A., M. GAČIĆ \& V. DADIĆ. 1996. Ecological study of gas fields in the northern Adriatic. Acta Adriat., 37(1/2): 17-34.

SOUSA, E.B., T. CRUZ \& J.J. CASTRO. 2000. Distribution and abundance of co-occurring chthamalid barnacles Chthamalus montagui and Chthamalus stellatus (Crustacea, Cirripedia) on the southwest coast of Portugal. Hydrobiologia, 440: 339-345.

SOUTHWARD, A.J. 1950. Distribution of Chthamalus stellatus on the shores of NorthEast Ireland. Nature, 166: 311.

SOUTHWARD, A.J. 1955. On the behavior of barnacles: I. The relation of cirral and other activities to temperature, J. Mar. Biol. Ass. U. K., 34(3): 403-422. 
SOUTHWARD, A.J. 1976. On the taxonomic status and distribution of Chthamalus stellatus (Cirripedia) in the North-East Atlantic region: with a key to the common intertidal Chthamalids of Britain. J. Mar. Biol. Ass. U. K., 56: 1007-1028.

SOUTHWARD, A.J. 1991. Forty years of changes in species composition and population density of barnacles on a rocky shore near Plymouth. J. Mar. Biol. Ass. U. K., 71: 445-513.

STACHOWITSCH, M. 1991. Anoxia in the northern Adriatic Sea: Rapid death, slow recovery. In: R. V. Tyson \& T. H. Pearson (Editors). Modern and Ancient Continental Shelf Anoxia, Geological Society Special Publication, 58: 119-129.

STEPHENSON, T.A. \& A. STEPHENSON. 1949. The universal feature of zonation between tidemarks on rocky coasts. J. Ecol., 37: 289-305.

STRAVISI, F. 1983. Some characteristics of the circulation in the Gulf of Trieste. Thalass. Jugosl., 19: 355-363.

VUČAK, Z. 1996. Ecological study of gas fields in the northern Adriatic: Tides. Acta Adriat., 37(1/2): $85-87$.
ZAVODNIK D. 1967. Dinamika litoralnega fitala na zahodnoistrski obali. Dissertationes Slovenska Akademija Znanosti in Umetnosti, Kl. 4., 10(1): 7-71.

ZAVODNIK, D. 1997. Chthamalus montagui and Platylepas hexastylos, two cirriped Crustaceans new to the Eastern Adriatic Sea. Nat. Croat., 6(1): 113-118.

ZAVODNIK, D., A. JAKLIN, M. RADOŠEVIĆ \& N. ZAVODNIK. 2000. Distribution of benthos at Jabuka, an islet of volcanic rock (Adriatic Sea). Period. Biol., 102(2): 157-167.

ZAVODNIK, D., A. PALLAORO, A. JAKLIN, M. KOVAČIĆ \& M. ARKO-PIJEVAC. 2005. A benthos of the Senj Archipelago (North Adriatic Sea, Croatia). Acta Adriat., 46(suppl.2): 3-68.

ZAVODNIK, D., M. LEGAC \& T. GLUHAK. 2006. An account of the marine fauna of Pag Island (Adriatic Sea, Croatia). Nat. Croat., 15(3): 65-107.

ZAVODNIK, N., IVEŠA, L. \& A. TRAVIZI. 2002. Note of recolonization by fucoid algae Cystoseira spp. and Fucus virsoides in the North Adriatic Sea. Acta Adriat., 43(1): 25-32. 


\title{
Vertikalna raspodjela i brojnost ciripednih rakova Chthamalus stellatus, Poli i Chthamalus montagui, Southward (Crustacea, Cirripedia) na dva lokaliteta na obalama istarskog poluotoka (sjeverni Jadran)
}

\author{
Nataša DOLENC-ORBANIĆ*1 i Claudio BATTELLI ${ }^{2}$ \\ *Kontakte-adresa: natasa.dolenc@pef.upr.si
}

\begin{abstract}
SAŽETAK
Dvije vrste ciripednih rakova vitičara dobro su razvijene od više do niže gornje granice mediolitoralne zone na stjenovitim obalama sjevernog Jadrana: rak vitičar brumbuljak (Chthamalus stellatus, Poli i Chthamalus montagui, Southward). Ova studija se bavi vertikalnom raspodjelom i brojnošću ovih vrsta na dva lokaliteta na obalama istarskog poluotoka (sjever Jadranskog mora). U tu svrhu su 2015. promatrane populacije ciripeda duž slovenske obale (Koparski zaljev, Tršćanski zaljev) te duž hrvatske obale u blizini Rovinja (zapadna obala Istre), obje na vapnencu. Glavni cilj istraživanja bio je utvrditi postoji li povezanost između vertikalne raspodjele i brojnosti ovih dvaju vrsta u različitim prostornim skalama: mala (među lokalitetima, otprilike jedan kilometar) i velika (među lokalitetima, deseci kilometara). Odabrani lokaliteti pomalo se razlikuju po rasponu plime i oseke, smještaju i izloženosti valovima. Nasumce su odabrana tri mjesta na svakome od ovih lokaliteta i dva presjeka za razinu plime i oseke (viši, srednji i niži) odabrana su na svakoj pojedinoj lokaciji. Brojnost pojedine vrste chthamalida u dijelovima od $1 \mathrm{dm}^{2}$ određeni su trima različitim razinama duž svakog presjeka. Rezultati su upućivali da je vertikalna raspodjela C. montagui i C. stellatus vrlo slična na svim lokacijama pa čak i na svim kontrolnim mjestima dok je njihova brojnost varirala. Na obje lokacije, C. montagui je bila brojnija pri nižim razinama plime i oseke. Također smo utvrdili da je C. montagui brojnija u zaštićenijim uvjetima (Koparski zaljev), dok je C. stellatus brojniji na obalama koje su izloženije valovima (blizu Rovinja), prilikom svih razina plime i oseke.
\end{abstract}

Ključne riječi: Chthamalus montagui, Chthamalus stellatus, vertikalna raspodjela, brojnost, prostorne varijacije, mediolitoral, sjeverni Jadran 